\title{
ROLE OF GUGGULUTIKTAKA GHRITA IN THE MANAGEMENT OF OSTEOARTHRITIS W.S.R. TO KNEE JOINT
}

\author{
Babasaheb D. Patil ${ }^{1 *}$, Manoj L. Sonaje ${ }^{2}$ \\ ${ }^{1}$ Associate Professor, Department of Samhita \& Basic Principle, L.K.R. Ayurveda Medical College \& PG Research \\ Centre, Gadhinglaj, Kolhapur, Maharashtra, India \\ ${ }^{2}$ Assistant Professor, Department of Shalyatantra, L.K.R. Ayurveda Medical College \& PG Research Centre., \\ Gadhinglaj, Kolhapur, Maharashtra, India
}

Received on: 13/10/12 Revised on: 30/11/12 Accepted on: 19/12/12

\author{
*Corresponding author \\ E-mail: drbabasahebpatil@gmail.com \\ DOI: $10.7897 / 2277-4343.04128$ \\ Published by Moksha Publishing House. Website www.mokshaph.com \\ All rights reserved.
}

\section{ABSTRACT}

Osteoarthritis is most widespread form of arthritis seen in elderly and knee joint pain is the most common complaint for which medical advice is sought in such circumstances. Major treatment for this complaint is prescription of established calcium compounds with NSAID's. But with this established treatment also total eradication of the pain is not possible. Basti (a medicated enema) in Ayurveda is practiced in many connective tissue disorders like Rheumatoid Arthritis, Osteoarthritis, Gout, Lumbar Sprain, Spondylosis etc. The present study was conducted at L.K.Redekar Ayurveda College and PG Research Centre Gadhinglaj Dist Kolhapur, India, with the aim and objective of assessing efficacy and safety of Guggulutiktaka ghrita in the management Knee Osteoarthritis. It's found that there is incredible role of guggulutiktaka ghrita in the management of sandhigatavata vis as vis Osteoarthritis

Keywords: Osteoarthritis, Guggulutiktaka Ghrita, Knee joint, Sandhigatavata

\section{INTRODUCTION}

Osteoarthritis is a foremost health problem considering its associated disability and impact on the quality of life. It is a leading cause of disability in elderly people ${ }^{1}$. Patients of osteoarthritis usually come with joint pain, stiffness and localized swelling which get worse in the morning and relieved after some movement in hour ${ }^{2}$. According to W.H.O. osteoarthritis is the second commonest musculoskeletal problem in the world population. In India osteoarthritis of knee joint is more common than hip joint $^{3}$. The incidence prevalence and availability of subjects knee joint arthritis was taken for the subject of interest.

Analgesics and NSAID's relive pain and improve function but prolonged use of these drugs may not be encouraged due to their adverse reactions. So it is a need of hour to find out alternate therapy to combat the pain as well as improve the quality of life of individual. A pilot clinical trial was designed to find out a solution to knee osteoarthritis with 'Guggulutiktaka Ghrita, which is vataghna (Vata pacifier) in nature. In Ayurvedic literature the Guggulu tiktaka ghrita is being used for treatment of asthimajja kshaya ${ }^{4}$ and also the combination explained in asthimajjagata Vata. This drug is mentioned by Ashtanga Hridaya in the management of bones and associated disoreders ${ }^{5}$.

\section{MATERIALS AND METHODS Selection of Patient}

The patients were selected irrespective of cast, creed, religion, sex from OPD and IPD Department of L.K.R. Ayurveda Hospital, Kolhapur, India, in the duration of Jan 2011-June 2012. The study was performed as per the
Ethical clearance outward number: LKRSS/AMCG/WS/7/PG/39/2012

The patients were selected via randomly selection method. The patients were clinically assessed and diagnosed on the basis of history and clinical examination. The patient who had clinical sign and symptoms of osteoarthritis was selected as per inclusion and exclusion criteria.

\section{Lab Investigations}

- Heamogram

- RA Test

- ASO Titer

- Serum Calcium

- Serum Uric Acid

Inclusive Criterion

- Age group from 40 - 80 years.

- Clinically and radiologically diagnosed patients of Knee Osteoarthritis

\section{Exclusive Criterion}

- Diabetes, Hypertension and all systemic disorder which can hamper its treatment were excluded

- Age group below 30 and above 80 were excluded

- Patients of fracture, Rheumatoid arthritis, Gout

Intervention

Name of Drug: Guggulu tiktaka Ghrita.

Reference: Ashtanga Hridaya

Indication: Bones and associate disorders

Route: Oral

Dose: $20 \mathrm{~g}$

Vehicle: Luke warm water

Frequency: Once in a day

Timing: Early in the morning 
Duration: 45 Days

Drug Review

Guggulutiktaka ghrita is mentioned in Ashtanga Hridaya. Ghrita was prepared as mentioned in sharandhara samhita.

Guggulutiktaka Ghrita contains

- Nimba (Azadirecta indica)

- Amrita (Tinospora cordifolia)

- Patol (Tricosanthus cucumerina)

- Kantakari (Solanum xanthocarpum)

- Vamsha (Bambusa arundinaccea)

- Amalaki (Emblica officinalis)

- Bibhitaki (Terminalia belerica)

- Haritaki (Terminalia chebula)

- Shunthi (Zinziber officinale)

- Maricha (Piper nigrum)

- Pippali (Piper longum)

- Musta (Cyperus rotandus)

- Haridra (Curcuma longa)

- Daruharidra (Berberis aristata)

- Vatsaka (Holarhena antidysentrica)
- Pippalimula (Piper longum Radix)

- Chitraka (Plumbago zylenica)

- Bhallataka (Semicarpus anacardium)

- Katuki (Picrorhiza kurrora)

- Ativisha (Aconitum heterophylum)

- Vacha (Acorus calamus)

- Vidanga (Emblia ribes)

- Yavakshara

- Sajjikshara

Assessment criteria

Subjective parameters

- Pain in the knee joints.

- Local Tenderness

- Morning stiffness duration.

- Localized swelling

The all gradation were adopted as per WOMAC Gradation Scale. $^{6}$

Objective parameters

Angle of extension and flexion (Goniometry)

\section{OBSERVATIONS AND RESULTS}

Table 1: Observations of Study

\begin{tabular}{|c|c|c|c|c|}
\hline $\mathrm{N}$ & Observation & Max Observation & Max no & $\%$ \\
\hline 31 & Sex & Male & 22 & 74.19 \\
\hline 31 & Age Group & $51-70$ & 26 & 83.87 \\
\hline 31 & Prakriti & Vata Kaphaja & 16 & 51.61 \\
\hline 31 & BMI & Normal Wt 18.5 to 24.9 & 23 & 74.19 \\
\hline 31 & Habitat & Rural & 26 & 83.87 \\
\hline 31 & Religion & Agrindulture & 30 & 96.77 \\
\hline 31 & Occupation & Poor & 17 & 54.83 \\
\hline 31 & Economic Status & Literate & 22 & 70.96 \\
\hline 31 & Educational Status & Rajasik & 19 & 70.96 \\
\hline 31 & Manasik Prakriti & Positive & 12 & 38.70 \\
\hline 31 & RA Test & Positive & 14 & 45.16 \\
\hline 31 & ASO Titer & Disturbed & 16 & 51.61 \\
\hline 31 & Sleep & Krura & 16 & 51.61 \\
\hline 31 & Koshta & Irregular & 17 & 54.83 \\
\hline 31 & Mala & Regular & 19 & 61.29 \\
\hline 31 & Mutra & Good & 18 & 58.06 \\
\hline 31 & Kshudha & Irregular Non veg Mixed & 25 & 80.64 \\
\hline 31 & Diet Type & Vishamasana & 26 & 83.87 \\
\hline 31 & Diet Habit & Labor & 16 & 51.61 \\
\hline 31 & Nature of work & Poor & 18 & 58.06 \\
\hline 31 & Nutrition & & & \\
\hline
\end{tabular}

Table 2: Statistical Analysis of Assessment parameter by Wilkoxn sign rank test

\begin{tabular}{|c|c|c|c|c|c|c|c|c|}
\hline Sign and Symptoms & $\mathrm{N}$ & & Median & $25 \%$ & $75 \%$ & $\mathrm{~W}$ & $\mathrm{t}$ & $\mathrm{P}$ \\
\hline \multirow[t]{2}{*}{ Localized swelling } & \multirow[t]{2}{*}{31} & BT & 27.0000 & 24.250 & 28.750 & \multirow[t]{2}{*}{-378.0} & \multirow[t]{2}{*}{-378.00} & \multirow[t]{2}{*}{$<0.001 *$} \\
\hline & & $\mathrm{AT}$ & 24.0000 & 21.250 & 26.000 & & & \\
\hline \multirow[t]{2}{*}{ Duration of morning Stiffness } & \multirow[t]{2}{*}{31} & BT & 60.000 & 32.500 & 120.00 & \multirow[t]{2}{*}{-496.0} & \multirow[t]{2}{*}{-496.00} & \multirow[t]{2}{*}{$<0.001 *$} \\
\hline & & AT & 0.000 & 0.000 & 60.000 & & & \\
\hline \multirow[t]{2}{*}{ Tenderness } & \multirow[t]{2}{*}{31} & BT & 2.000 & 2.000 & 3.000 & \multirow[t]{2}{*}{-406.0} & \multirow[t]{2}{*}{-406.00} & \multirow[t]{2}{*}{$<0.001^{*}$} \\
\hline & & $\mathrm{AT}$ & 1.000 & 0.000 & 1.000 & & & \\
\hline \multirow[t]{2}{*}{ Pain In Knee Joints } & \multirow[t]{2}{*}{31} & BT & 3.000 & 3.000 & 3.000 & \multirow[t]{2}{*}{-465.00} & \multirow[t]{2}{*}{-465.00} & \multirow[t]{2}{*}{$<0.001^{*}$} \\
\hline & & AT & 1.000 & 0.000 & 1.000 & & & \\
\hline
\end{tabular}

Table 3: Statistical Analysis of Assessment parameter by paired't' test

\begin{tabular}{|c|c|c|c|c|c|c|c|c|}
\hline Sign and Symptoms & $\mathrm{N}$ & & Mean & MD & SD & SEM & $\mathrm{T}$ & $\mathrm{P}$ \\
\hline \multirow[t]{2}{*}{ Angle of Extension and Flexion } & \multirow[t]{2}{*}{31} & BT & 95.613 & \multirow[t]{2}{*}{36.355} & 18.457 & 3.315 & \multirow[t]{2}{*}{8.888} & \multirow[t]{2}{*}{$<0.001^{*}$} \\
\hline & & AT & 59.258 & & 17.344 & 3.115 & & \\
\hline
\end{tabular}


As per statistical analysis it was found that Guggulutiktaka Ghrita have significant role in reducing all subjective and objective parameters of Knee joint arthritis with $\mathrm{p}$ value $<0.001$.

\section{DISCUSSION}

The disease is found in elderly, in dry and suburban region, the male is more prone to disease due to physical hard work. The malnourish peoples found more in particular study. The overall improvement in various clinical parameters according to Ayurveda might be a result of elimination of vitiated Vatadosha and decrease in the dhatukshaya and also reducing the inflammation by the application of tiktarasa dravyas. There was no any adverse effect noticed during or after the treatment. It was not known that what is the role of this therapy in long term management of osteoarthritis. Does it recur or not or it vanishes totally. For this purpose a separate study may be beneficial.

\section{CONCLUSION}

On the basis of this pilot study we can say that administration of Guggulutiktaka Ghrita is an effective medicine in reduction of pain, swelling, tenderness and restrictions to movements without any noxious effect which is very important.

\section{ACKNOWLEDGEMENT}

Authors are grateful to directors and principal of L.K.Redekar Ayurveda College Gadhinglaj. We are also grateful to our patients without whom this study would not have been possible.

\section{REFERENCES}

1. H Bassiouni. Relating bone marrow oedema to HS-CRP in knee osteoarthritis. Indian Journal of Rhematology 2010;5(1):11-15 http://dx.doi.org/10.1016/S0973-3698(10)60530-4

2. Hans lund. A randomized controlled trial and land based exercise in patients with knee joint arthritis. J Rehabil Med 2008; 40: 137-144 http://dx.doi.org/10.2340/16501977-0134 PMid:18509579

3. Christopher Haslett and others. Davidson's principles and practice of medicine: chapter no 20 Musculoskeletal disorders, $19^{\text {th }}$ edition, Churchil Livingstone publication, edition 2002, p 997

4. Vaghbhata. Ashtanga Hridaya with sarvangasundar commentary edited by Harishastri paradkar, $7^{\text {th }}$ edition, choukhamba orientalia $1982, \mathrm{p} 726,27$

5. Vaghbhata. Ashtanga Hridaya with sarvangasundar commentary edited by Harishastri paradkar, $7^{\text {th }}$ edition, choukhamba orientalia 1982, p723

6. S. Sontakke. Open RCT of Boswella serrata extract in OA of knee: Indian Journal of pharmacology, 2007;39(1):27-29

7. Kshipra Rajoria. Clinical study on Laksha Guggulu, Snehana, Swedana and Traction in Osteoarthritis (Knee joint). Аyu 2010;31(1): $\quad 80-87 \quad$ http://dx.doi.org/10.4103/0974-8520.68192 PMid:22131690 PMCid:3215328

Cite this article as:

Babasaheb D. Patil, Manoj L. Sonaje. Role of Guggulutiktaka ghrita in the management of Osteoarthritis w.s.r. to knee joint. Int. J. Res. Ayur. Pharm. 2013; 4(1): 71-73 